medRxiv preprint doi: https://doi.org/10.1101/2021.07.05.21259952; this version posted July 7,2021 . The copyright holder for this preprint

(which was not certified by peer review) is the author/funder, who has granted medRxiv a license to display the preprint in perpetuity. It is made available under a CC-BY-ND 4.0 International license.

\title{
Prevalence and risk factors of short birth interval in Bangladesh: Evidence from the linked data of population and health facility survey
}

Mohammad Zahidul Islam, MSc ${ }^{1,3}$, M Mofizul Islam, $\mathrm{PhD}^{2}$, Md. Mostafizur Rahman, $\mathrm{PhD}^{2}$, Md. Nuruzzaman Khan, $\mathrm{PhD}^{1}$

1. Department of Population Science, Jatiya Kabi Kazi Nazrul Islam University, Trishal, Mymensingh, Bangladesh

2. Department of Public Health, La Trobe University, Melbourne, Australia.

3. Department of Population Science and Human Resource Development, Rajshahi University, Bangladesh

Short title: Determinants of Short Birth Interval in Bangladesh

\section{Corresponding author}

\section{Mohammad Zahidul Islam}

$\mathrm{PhD}$ Student

Department of Population Science and Human Resource Development

University of Rajshahai, Rajshahi-6205, Bangladesh.

Email: zahid100779@gmail.com 
medRxiv preprint doi: https://doi.org/10.1101/2021.07.05.21259952; this version posted July 7,2021 . The copyright holder for this preprint (which was not certified by peer review) is the author/funder, who has granted medRxiv a license to display the preprint in perpetuity. It is made available under a CC-BY-ND 4.0 International license.

\begin{abstract}
Background: The Sustainable Development Goals target significant reductions in maternal and under-five deaths by 2030. The prevalence of these deaths is significantly associated with short birth interval (SBI). Identification of factors associated with SBI is pivotal for intervening with appropriate programmes to reduce these adverse consequences. This study aimed to determine the factors associated with SBI in Bangladesh.
\end{abstract}

Methods: The Bangladesh Demographic and Health Survey 2017/18 and Bangladesh Health Facility Data 2017 were linked and analysed. SBI was defined as an interval between consecutive births of 33 months or less, as recommended by the World Health Organization. We used descriptive statistics to summarise respondents' characteristics and multilevel Poisson regression to assess the predictors of SBI.

Results: Around $26 \%$ of live births occurred in short intervals, with a further higher prevalence among younger, uneducated, or rural women. The likelihoods of SBI were lower among women aged 20-34 years (PR, 0.14; 95\% CI, 0.11-0.17) and $\geq 35$ years (PR, 0.03; 95\% CI, 0.02-0.05) as compared to the women aged 19 years or less. Women from households with the richest wealth quintile experienced lower odds of SBI (PR, 0.61; 95\% CI, 0.45-0.85) compared to those from the poorest wealth quintile. The prevalences of SBI were higher among women for whom the children born from the second most pregnancies died (PR, 5.23; 95\% CI, 4.186.55), those who were living in Chattogram (PR, 1.52; 95\% CI, 1.12-2.07) or Sylhet (PR, 2.83, 95\% CI, 2.08-3.86) divisions. Availability of modern contraceptives at the nearest healthcare facilities was $66 \%$ protective to the occurrence of SBI (PR, 0.34; 95\% CI, 0.22-0.78). Also, the prevalence of SBI increased around $85 \%$ (PR, 1.85; 95\% CI, 1.33-2.18) for every kilometer increase in the distance of nearby health facilities from women's homes. 
medRxiv preprint doi: https://doi.org/10.1101/2021.07.05.21259952; this version posted July 7, 2021. The copyright holder for this preprint (which was not certified by peer review) is the author/funder, who has granted medRxiv a license to display the preprint in perpetuity. It is made available under a CC-BY-ND 4.0 International license.

Conclusion: More than a quarter of live births in Bangladesh occurred in short intervals. This relatively high prevalence is a challenge for Bangladesh in reducing pregnancy-related adverse consequences, including maternal and child mortality. Policies and programmes are needed to increase awareness of SBI and associated adverse health outcomes and expand access to modern contraceptives.

Keywords: Short birth interval, Demographic and Health Survey, Sustainable Development Goals, Bangladesh. 
medRxiv preprint doi: https://doi.org/10.1101/2021.07.05.21259952; this version posted July 7, 2021. The copyright holder for this preprint (which was not certified by peer review) is the author/funder, who has granted medRxiv a license to display the preprint in perpetuity. It is made available under a CC-BY-ND 4.0 International license.

\section{Introduction}

The World Health Organization (WHO) recommends at least 24 months interval between a live birth or termination to the next conception or 33 months interval between a live birth or termination to the next live birth (1). The intervals shorter than these durations are considered as short birth intervals (SBI), which are associated with several adverse health outcomes, including preterm birth $(2,3)$, low birth-weight $(2,3)$ and small for gestational age (3). Neonatal and infant mortality are also found to be higher among children born in SBI $(3,4)$. Maternal morbidities such as preeclampsia, high blood pressure, and premature rupture of the membrane are also found higher among mothers having a conception in short intervals of the previous birth. Importantly, these are the major causes of around 822 maternal deaths in a day in lowand lower-middle-income countries (LMICs) $(5,6)$.

Globally, around $25 \%$ of live births occur in short intervals, with relatively high proportions in Central Asia (33\%) and Sub-Saharan Africa (57\%) (7). In Bangladesh, the prevalence is around $26 \%$ and equates to over a million live births in a year (8). Like many other LMICs, this high number of births in short intervals caused a large-scale of several adverse health outcomes $(9,10)$ including maternal and child mortality $(6)$ and prevented Bangladesh from achieving the relevant Millennium Development Goals during the period 2000-2015. Reduction of these adverse health outcomes is a priority of the Sustainable Development Goals, which will require substantially reduce the prevalence of births in SBI through initiating policies and programmes.

Knowledge of the current prevalence of SBI and associated factors are essential for appropriate policy and programme development to reduce SBI. However, there are at least two challenges in Bangladesh and other LMICs that make these difficult, which are (i) inaccurate measurement of SBI and (ii) inconsistent list of factors associated with SBI. Most studies conducted in 
medRxiv preprint doi: https://doi.org/10.1101/2021.07.05.21259952; this version posted July 7, 2021. The copyright holder for this preprint (which was not certified by peer review) is the author/funder, who has granted medRxiv a license to display the preprint in perpetuity. It is made available under a CC-BY-ND 4.0 International license.

Bangladesh and similar settings used 24 months interval from one birth to the next birth for measuring SBI, instead of the WHO recommendation of 33 months. In the context of Bangladesh, previous studies used inconsistent duration in defining SBI, including $<24$ months (11), <33 months (12), <36 months (10) and <39 months (13). The factors associated with SBI are also inconsistent across the studies (14-18). Most of these studies considered only a limited set of confounding factors, mainly the individual-level factors including women's age, education, occupation $(12,16,19)$ and/or analysed small datasets (19). Moreover, some studies used single-level logistic regression although their data were hierarchical where single-level analysis often produces imprecise results $(10,11,13,20)$. Furthermore, healthcare facility-level factors such as distance from participants' houses were rarely taken into account $(21,22)$. This study aimed to assess the multidimensional factors associated with SBI in Bangladesh using the WHO classification of SBI and using a wide range of confounding factors.

\section{Methods}

\section{Study overview}

Data analysed in this study come from the nationally representative Bangladesh Demographic and Health Survey (BDHS) 2017/18 and Bangladesh Health Facility Survey (BHFS) 2017. The geographic variables (GPS point location) of these datasets were linked using the administrative boundary link. The detail for this method has been published elsewhere $(23,24)$. The sampling procedure of both surveys can be found in the respective survey reports $(25,26)$.

The 2017/18 BDHS was conducted by the National Institute of Population Research and Training as part of the Demographic and Health Survey (DHS) program and supervised by the Ministry of Health and Family Welfare of Bangladesh. The survey interviewed 20,127 reproductive-aged ever-married women selected through a two-stage stratified random sampling procedure. At the first stage, 675 primary sampling units (PSUs) were selected 
medRxiv preprint doi: https://doi.org/10.1101/2021.07.05.21259952; this version posted July 7,2021 . The copyright holder for this preprint (which was not certified by peer review) is the author/funder, who has granted medRxiv a license to display the preprint in perpetuity. It is made available under a CC-BY-ND 4.0 International license.

randomly from the list of 293,579 PSUs generated by the Bangladesh Bureau of Statistics as part of the 2011 National Population Census. Data were collected from 672 of these PSUs and the remaining three were excluded due to flood. At the second stage of sampling, 30 households were selected randomly from each of the selected PSUs. This produced a list of 20,160 households, among which interview was conducted in 19,457 households.

The 2017 BHFS is the source of healthcare facility data in Bangladesh. The survey collected data from 1,524 healthcare facilities selected proportionately from the public, private and nongovernment sectors. Both census and stratified random sampling methods were used to select these facilities from the 19,811 registered healthcare facilities in Bangladesh.

\section{Sample}

Of the 20,127 women included in the 2017/18 BDHS, 5,941 women were included in this study. The inclusion criteria were i) had at least two pregnancies, of which the most recent one occurred within five years of the survey date and ended with live birth, (ii) the second most recent pregnancy ended either with live birth or termination and (ii) the date of live birth after the most recent pregnancy and the date of birth or termination after the second most recent pregnancy were recorded.

\section{Outcome variable}

In this study, SBI is the outcome variable. The BDHS recorded the interval between the end of the second last pregnancy through termination or live birth to the end of the most recent pregnancy through live birth. We categorised these data in line with the WHO's recommendation to define SBI. Thus, births were considered to have occurred in short intervals if the last live births occurred at 33 months or lesser intervals of the second last live births or terminations (1). 
medRxiv preprint doi: https://doi.org/10.1101/2021.07.05.21259952; this version posted July 7, 2021. The copyright holder for this preprint (which was not certified by peer review) is the author/funder, who has granted medRxiv a license to display the preprint in perpetuity. It is made available under a CC-BY-ND 4.0 International license.

\section{Exposure variables}

A comprehensive literature search was conducted in five databases (Medline, Embase, Web of Science, CINHAL, and Google Scholar) to identify potential determinants of SBI $(10,11,13-$ 18,20). Factors identified were then summarised as individual-, household- and communitylevel factors. Individual-level factors were maternal age at birth $(\leq 19,20-34, \geq 35$ years $)$, maternal age at first birth (used as a continuous variable), maternal educational status (no formal education, primary, secondary, higher), and mothers' employment status at the time of the survey (employed, unemployed). Household-level factors were partners' educational status (no formal education, primary, secondary, higher), sex of the household's head (male, female), the total number of children ever given birth $(\leq 2,>2)$, exposure to mass media (little exposed, moderately exposed, highly exposed), survival status of the child born from the second most pregnancy (yes, no), and wealth quintile (poorest, poorer, middle, richer, richest). Place of residence (urban, rural) and region (seven administrative divisions, namely Barishal, Chattogram, Dhaka, Khulna, Mymensingh, Rajshahi, Rangpur, Sylhet) were the communitylevel factors. To our knowledge, this is the first study in Bangladesh and other LMICs that considered the health facility-level factors because of their potential role in modern contraception use in SBI $(21,27,28)$. We generated four health service variables: average distance to the nearest family planning facility, family planning service availability, readiness to provide family planning services, and general health facility readiness. The details of this approach can be found elsewhere $(28,29)$.

\section{Statistical analysis}

Descriptive statistics with frequency and percentage distribution were used to describe the characteristics of the respondents. The distribution of SBI across individual- and householdlevel characteristics was also examined. Statistical significance of the difference in distribution 
medRxiv preprint doi: https://doi.org/10.1101/2021.07.05.21259952; this version posted July 7, 2021. The copyright holder for this preprint (which was not certified by peer review) is the author/funder, who has granted medRxiv a license to display the preprint in perpetuity. It is made available under a CC-BY-ND 4.0 International license .

was assessed using the chi-square test. Availability of modern contraceptives across facility types and division were also explored. The data were hierarchical, as respondents were nested in the households, and households nested in the PSU. Therefore, we expected responses from the same household and cluster would behave more alike than different households and clusters (30). Moreover, the outcome of this study, i.e., SBI, is a common outcome. Previous studies found simple logistic regression models often overestimate the odds for a common outcome and hierarchical data $(30,31)$. Therefore, we used multilevel Poisson regression model that accounts for these multiple hierarchies and dependency in data, and the problem of overestimation (32). Five models were run separately. Model 1 was the intercept-only model, presenting variance in prevalence of SBI across PSUs. Model 2 included all individual- and household-level factors. Model 3 included community-level factors. In model 4, health facilitylevel variables were included. Model 5 was the final model that included all factors. We checked multicollinearity before entering these variables into the models. If evidence of multicollinearity was found (VIF>10), the relevant variable was deleted. Results were reported as Prevalence Ratios (PR) with 95\% Confidence Intervals $(95 \% \mathrm{CI})$. The Intra-Class Correlation (ICC), Variance Inflation Factor (VIF), AIC and BIC for each model were recorded and compared to select the best model. The ICC value was calculated by dividing the betweenclusters-variance of SBI (random intercept variance) by the total variance of SBI (sum of between-clusters-variance and within-cluster (residual) variance of SBI). Geographical linkage between survey and health facility data was performed using the Statistical package R. All other statistical analyses were conducted using Stata version 15.1 (Stata Corp, College Station, Texas, USA). 
medRxiv preprint doi: https://doi.org/10.1101/2021.07.05.21259952; this version posted July 7, 2021. The copyright holder for this preprint (which was not certified by peer review) is the author/funder, who has granted medRxiv a license to display the preprint in perpetuity. It is made available under a CC-BY-ND 4.0 International license.

\section{Result}

\section{Socio-demographic characteristics of the respondents}

Table 1 shows the background characteristics of the respondents. A majority $(86.24 \%)$ of women were 20-34 years old and one-fourth reported that they had their first birth before reaching 19. Around half of respondents had completed secondary-level education and $86 \%$ reported that the head of the household was a man. Overall, $8 \%$ of respondents reported that the child born from their second most recent pregnancy had died.

Table 1: Demographic characteristics of the respondents $(N=5,941)$

\begin{tabular}{|c|c|c|c|c|}
\hline \multirow[t]{2}{*}{ Characteristics } & \multirow[t]{2}{*}{ Total } & \multicolumn{2}{|c|}{ Short birth interval } & \multirow[t]{2}{*}{$p^{1}$} \\
\hline & & Yes $(n=1566)$ & No $(n=4375)$ & \\
\hline \multicolumn{5}{|l|}{ Maternal age at birth } \\
\hline$\leq 19$ & $463(7.80)$ & $314(20.06)$ & $149(3.41)$ & \multirow[t]{3}{*}{$<0.01$} \\
\hline $20-34$ & $5124(86.24)$ & $1222(78.00)$ & $3902(89.18)$ & \\
\hline$\geq 35$ & $354(5.96)$ & $30(1.93)$ & $324(7.41)$ & \\
\hline \multicolumn{5}{|l|}{ Maternal age at first birth } \\
\hline$\leq 19$ & $4467(75.19)$ & $1138(72.65)$ & $3329(76.10)$ & \multirow[t]{3}{*}{$<0.05$} \\
\hline $20-34$ & $1468(24.71)$ & $424(27.08)$ & $1044(23.86)$ & \\
\hline$\geq 35$ & $6(0.10)$ & $4(0.27)$ & $2(0.04)$ & \\
\hline \multicolumn{5}{|l|}{ Mother's educational status } \\
\hline No education & $568(9.55)$ & $152(9.66)$ & $416(9.51)$ & \multirow[t]{4}{*}{$<0.01$} \\
\hline Primary & $1961(33.01)$ & $547(34.95)$ & $1414(32.31)$ & \\
\hline Secondary & $2794(47.03)$ & $681(43.51)$ & $2113(48.29)$ & \\
\hline Higher & $618(10.41)$ & $186(11.87)$ & $432(9.88)$ & \\
\hline \multicolumn{5}{|l|}{ Mother's working status } \\
\hline Yes & $2781(46.81)$ & $670(42.77)$ & $2111(48.25)$ & \multirow[t]{2}{*}{$<0.01$} \\
\hline No & $3160(53.19)$ & $896(57.23)$ & $2264(51.75)$ & \\
\hline \multicolumn{5}{|l|}{ Partner's educational status } \\
\hline No education & $1079(18.43)$ & $273(17.72)$ & $806(18.68)$ & \multirow[t]{4}{*}{$<0.05$} \\
\hline Primary & $2179(37.22)$ & $620(40.15)$ & $1559(36.17)$ & \\
\hline Secondary & $1751(29.91)$ & $412(26.71)$ & $1339(31.05)$ & \\
\hline Higher & $846(14.44)$ & $238(15.42)$ & $608(14.09)$ & \\
\hline \multicolumn{5}{|l|}{ Sex of the household's head } \\
\hline Male & $5114(86.09)$ & $1383(88.34)$ & $3731(85.28)$ & \multirow[t]{2}{*}{$<0.05$} \\
\hline Female & $827(13.91)$ & $183(11.66)$ & $644(14.72)$ & \\
\hline \multicolumn{5}{|l|}{ Total children ever born } \\
\hline$\leq 2$ & $3075(51.75)$ & $886(56.56)$ & $2189(50.03)$ & \multirow[t]{2}{*}{$<0.01$} \\
\hline$>2$ & $2866(48.25)$ & $680(43.44)$ & $2186(49.97)$ & \\
\hline
\end{tabular}

Exposure to mass media 
medRxiv preprint doi: https://doi.org/10.1101/2021.07.05.21259952; this version posted July 7,2021 . The copyright holder for this preprint (which was not certified by peer review) is the author/funder, who has granted medRxiv a license to display the preprint in perpetuity. It is made available under a CC-BY-ND 4.0 International license .

\begin{tabular}{|c|c|c|c|c|}
\hline Little exposed & $2289(38.52)$ & $650(41.51)$ & $1639(37.45)$ & \multirow[t]{3}{*}{$<0.01$} \\
\hline Moderate exposed & $788(13.26)$ & $250(15.94)$ & $538(12.31)$ & \\
\hline Highly exposed & $2864(48.21)$ & $666(42.55)$ & $2198(50.24)$ & \\
\hline \multicolumn{5}{|l|}{$\begin{array}{l}\text { Child born from the second } \\
\text { most pregnancy was alive }\end{array}$} \\
\hline Yes & $5458(91.88)$ & $1254(80.09)$ & $4204(96.10)$ & \multirow[t]{2}{*}{$<0.01$} \\
\hline No & $483(8.12)$ & $312(19.91)$ & $171(3.90)$ & \\
\hline \multicolumn{5}{|l|}{ Wealth quintile } \\
\hline Poorest & $1439(24.22)$ & $415(26.51)$ & $1024(23.40)$ & \multirow[t]{5}{*}{$<0.01$} \\
\hline Poorer & $1287(21.65)$ & $381(24.30)$ & $906(20.70)$ & \\
\hline Middle & $1066(17.95)$ & $260(16.62)$ & $806(18.43)$ & \\
\hline Richer & $1097(18.47)$ & $274(17.50)$ & $823(18.82)$ & \\
\hline Richest & $1052(17.71)$ & $236(15.06)$ & $816(18.66)$ & \\
\hline \multicolumn{5}{|l|}{ Type of residential place } \\
\hline Urban & $1543(25.97)$ & $375(23.98)$ & $1168(26.69)$ & \multirow[t]{2}{*}{$<0.05$} \\
\hline Rural & $4398(74.03)$ & $1191(76.02)$ & $3207(73.31)$ & \\
\hline \multicolumn{5}{|l|}{ Administrative division } \\
\hline Barishal & $333(5.61)$ & $71(4.57)$ & $262(5.99)$ & \multirow[t]{8}{*}{$<0.01$} \\
\hline Chattogram & $1312(22.08)$ & $379(24.17)$ & $933(21.33)$ & \\
\hline Dhaka & $1466(24.67)$ & $352(22.48)$ & $1114(25.45)$ & \\
\hline Khulna & $502(8.45)$ & $100(6.41)$ & $402(9.18)$ & \\
\hline Mymensingh & $507(8.54)$ & $142(9.10)$ & $365(8.34)$ & \\
\hline Rajshahi & $643(10.82)$ & $138(8.78)$ & $505(11.55)$ & \\
\hline Rangpur & $626(10.53)$ & $130(8.27)$ & 496 (11.34) & \\
\hline Sylhet & $552(9.30)$ & $254(16.22)$ & $298(6.82)$ & \\
\hline
\end{tabular}

Note: ${ }^{1}$ The significance level was estimated using the Chi-square test. Fisher exact test was used for maternal age at first birth.

\section{Distribution of short birth intervals across socio-demographic characteristics}

Over $26 \%$ of respondents had their last birth in a short interval of their second most recent birth. The prevalence of SBI was higher among respondents aged 20-34 years (78\%), who had their first birth $\leq 19$ years $(72.65 \%)$, or not engaged in formal work $(57.23 \%)$. SBI was also higher among respondents who had $\leq 2$ children at the time of the survey $(56.56 \%)$, not exposed to mass media $(41.51 \%)$ or had their child born from the second most pregnancy died $(19.91 \%)$.

\section{Characteristics of health facilities and their distribution}

The division-wise distribution of health facilities that provided modern contraceptives and their average distance from BDHS clusters are presented in Table 2. 
Table 2: Distribution of health facilities that delivered modern contraception and their average distance from the clusters

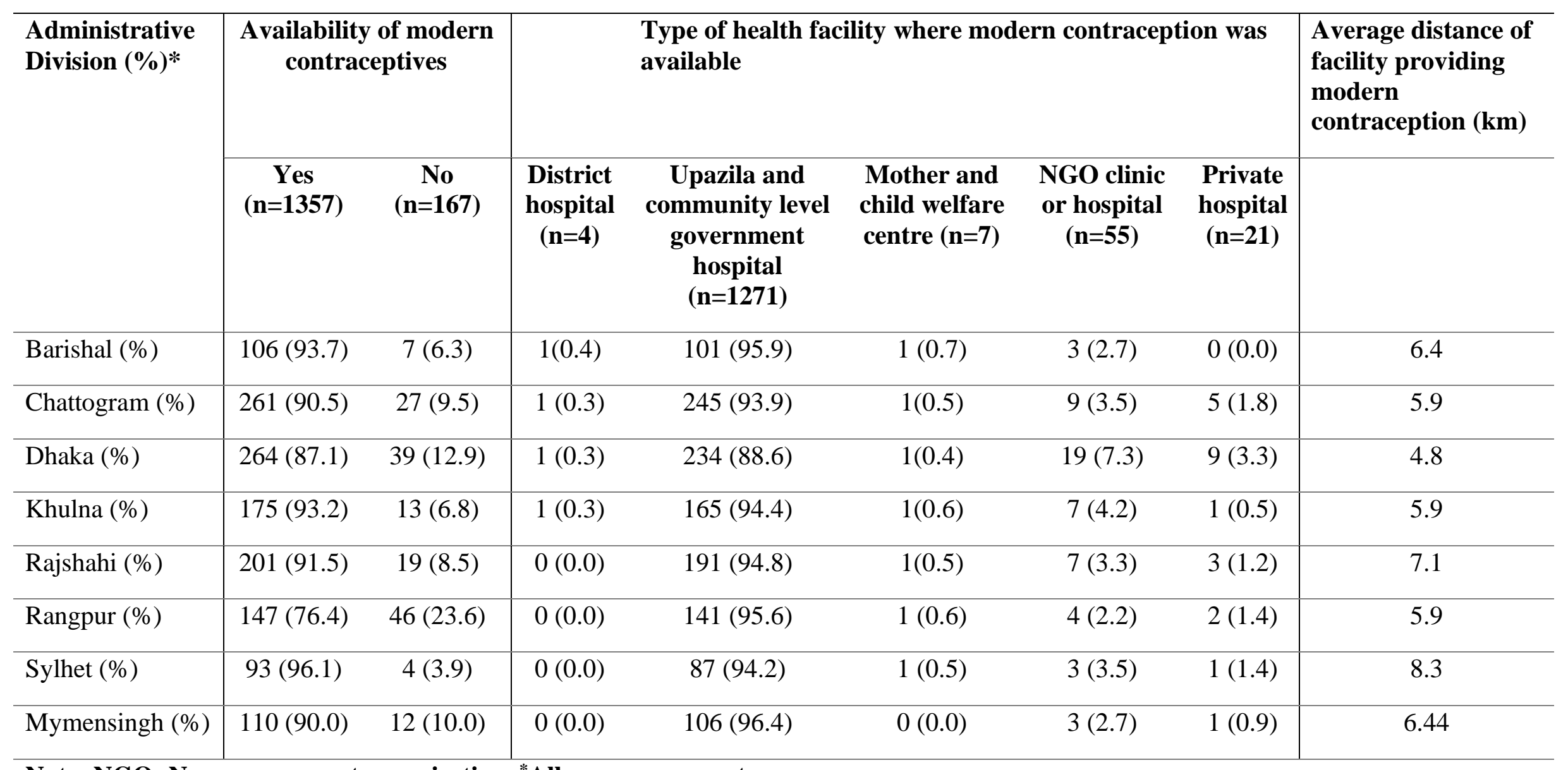

Note: NGO: Non-government organisation, *All are row percentage 
medRxiv preprint doi: https://doi.org/10.1101/2021.07.05.21259952; this version posted July 7,2021 . The copyright holder for this preprint

Around $89 \%$ (1357/1524) of health facilities included in the 2017 BHFS provided modern contraceptives to the clients. Upazila to community-level government hospitals were the major providers of modern contraceptives (93\%). The national average distance of modern contraception-providing health facilities from respondents' houses was $6.36 \mathrm{~km}$. This distance was higher in the Sylhet division $(8.34 \mathrm{~km})$ and lower in the Chattogram division $(5.85 \mathrm{~km})$.

\section{Age-standardised prevalence of short birth intervals}

We calculated the age-standardised prevalence of SBI across regions in Bangladesh (Figure 1, results not shown in the table) as there were substantial variations in the prevalences of SBI in Bangladesh across different age-groups of women. The distribution of women aged 15-49 in the 2011 national population census was used for standardisation. The age-standardised prevalence of SBI in the Sylhet region was $44.14 \%$, almost two times higher than that in the Barishal region (22.20\%). 


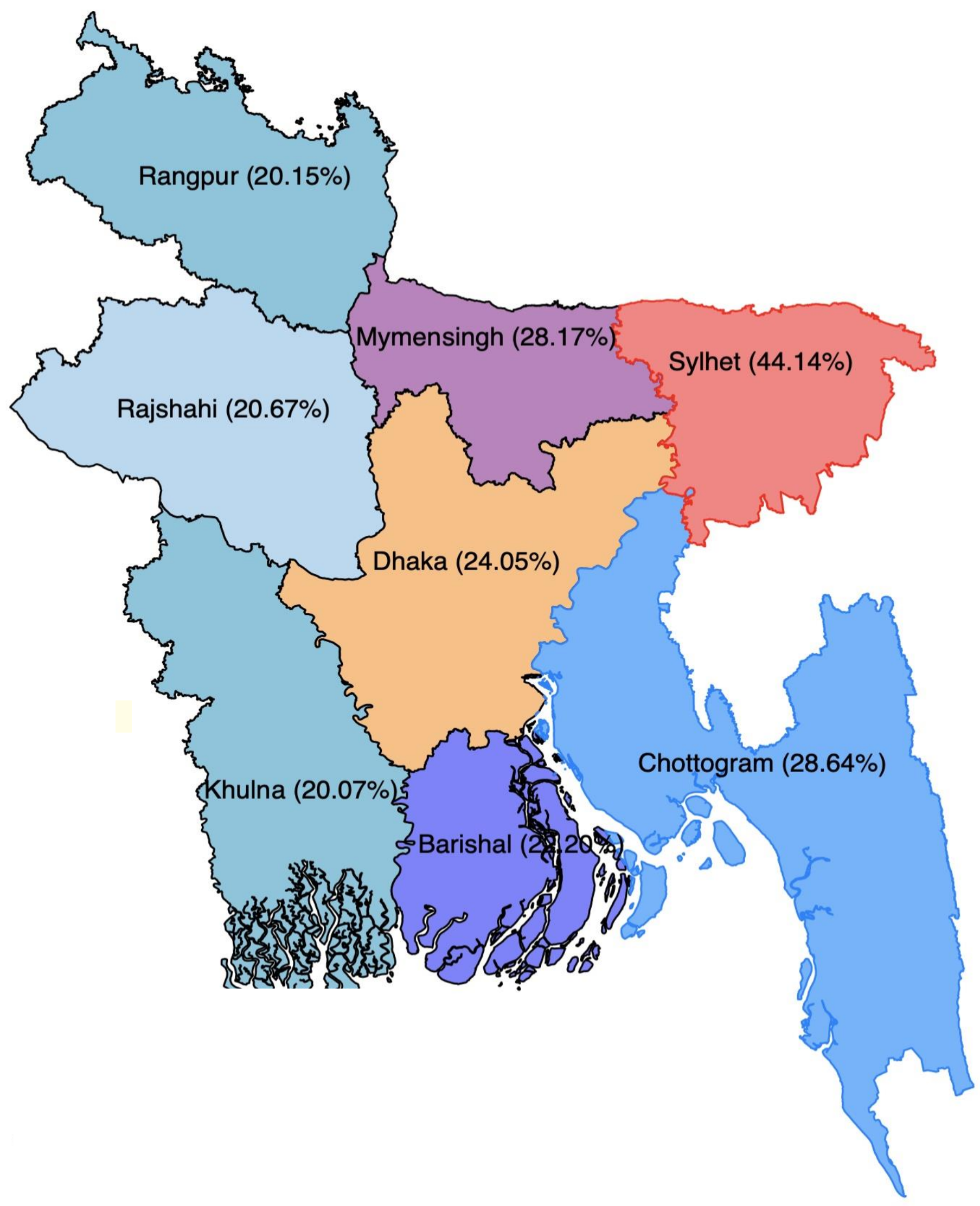

Figure 1 Age-standardised prevalence of short birth intervals in Bangladesh, BDHS 2017/18. 
medRxiv preprint doi: https://doi.org/10.1101/2021.07.05.21259952; this version posted July 7,2021 . The copyright holder for this preprint (which was not certified by peer review) is the author/funder, who has granted medRxiv a license to display the preprint in perpetuity. It is made available under a CC-BY-ND 4.0 International license .

\section{Model diagnosis}

Of the five models conducted separately with individual-, household-, community-, and the health facility-level confounders, the best model was selected by comparing the model statistics including Akaike's information criterion (AIC), Bayesian information criterion (BIC), and intra-class correlation (ICC). The best model was the one that had the smallest AIC, BIC and ICC. According to these markers, Model 5 that included individual-, household-, community, and health facility-level variables was the best. The ICC in the null model was $18.92 \%$, which was reduced to $4.12 \%$ once individual-, household-, community-, and health facility-level factors were adjusted in Model 5.

Table 4: Results from random intercept model (measure of variation) to assess the factors associated with short birth interval at the individual and household, community, and health facility level, BDHS 2017/18.

\begin{tabular}{|c|c|c|c|c|c|}
\hline $\begin{array}{l}\text { Random effects } \\
\text { (Measure of } \\
\text { variation for } \\
\text { short birth } \\
\text { interval) }\end{array}$ & Model 1 & Model 2 & Model 3 & Model 4 & Model 5 \\
\hline $\begin{array}{l}\text { Community level } \\
\text { variance (SE) }\end{array}$ & $0.85(1.35)^{* * *}$ & $\begin{array}{c}1.20 \\
(1.36)^{* * *}\end{array}$ & $\begin{array}{c}0.46 \\
(0.06)^{* * * *}\end{array}$ & $\begin{array}{c}0.37 \\
(0.06)^{* * *}\end{array}$ & $\begin{array}{c}0.42 \\
(0.06)^{* * *}\end{array}$ \\
\hline ICC & 0.1892 & 0.13 & 0.06 & 0.05 & 0.0412 \\
\hline $\mathrm{PCV}$ & Reference & $27.78 \%$ & $66.67 \%$ & $72.22 \%$ & $77.78 \%$ \\
\hline $\begin{array}{l}\text { Median Odds } \\
\text { Ratio }\end{array}$ & 2.25 & 3.15 & 1.54 & 1.84 & 1.49 \\
\hline \multicolumn{6}{|l|}{$\begin{array}{l}\text { Model fit } \\
\text { statistics }\end{array}$} \\
\hline AIC & 6980.60 & 6104.71 & 6756.93 & 7736.93 & 5927.44 \\
\hline $\mathrm{BIC}$ & 7000.67 & 6251.57 & 6863.98 & 7864.98 & 6161.06 \\
\hline
\end{tabular}


medRxiv preprint doi: https://doi.org/10.1101/2021.07.05.21259952; this version posted July 7,2021 . The copyright holder for this preprint (which was not certified by peer review) is the author/funder, who has granted medRxiv a license to display the preprint in perpetuity.

\section{Predictors of short birth intervals}

The results of the multilevel Poisson regression models examining factors associated with SBI are presented in Table 5. There was a decline in the prevalence of SBI with the increasing age of respondents. The PR was $86 \%$ (PR, 0.14; 95\% CI, 0.11-0.17) and 97\% (PR, 0.03; 95\% CI, 0.02-0.05) lower among the respondents aged 20-34 years and $\geq 35$ years, respectively, compared to the respondents aged $\leq 19$ years. For each year increase in age at first birth leads to a $31 \%$ decrease in the prevalence of SBI (95\% CI, 0.59-0.86). The PR was around $25 \%$ (PR,0.75; 95\% CI, 0.61-0.93) lower among women residing in the female-headed households than those in the male-headed households. The PR of SBI was 5.23 (95\% CI, 4.18-6.55) times higher for women whose second most recent child died compared to women whose second most recent child was alive. This study found a 39\% (95\% CI, 0.45-0.85) decline in the prevalence of SBI among respondents who belong to the richest wealth quintile than the respondents with the poorest wealth quintile. Respondents living in the Chattogram (PR, 1.52; 95\% CI, 1.12-2.07) and Sylhet (PR, 2.83; 95\% CI, 2.08-3.86) divisions reported a higher PR of SBI than those in the Barishal region. At the health facility level, we found PR of SBI declined around 32\% (PR, 0.68; 95\% CI, 0.54-0.95) and 66\% (95\% CI; 0.22-0.58) if the nearest health facilities provided the long-acting and short-acting modern contraceptives, respectively. We found that for every kilometer increase in distance of the nearest health facilities that provide modern contraceptives, women were 1.85 times (95\% CI, 1.33-2.18) more likely to report a birth or pregnancy in short intervals. 
Table 5: Multilevel Poisson regression examining associated factors of short birth intervals in Bangladesh $(\mathrm{N}=5,941)$

\begin{tabular}{|c|c|c|c|c|c|}
\hline Characteristics & Null model & $\begin{array}{l}\text { Individual- and } \\
\text { household- level } \\
\text { model, PR (95\% } \\
\text { CI) }\end{array}$ & $\begin{array}{l}\text { Community level } \\
\text { model, PR (95\% } \\
\text { CI) }\end{array}$ & $\begin{array}{l}\text { Health facility } \\
\text { model, PR } \\
(95 \% \text { CI })\end{array}$ & $\begin{array}{c}\text { Individual-, household-, } \\
\text { community, health } \\
\text { facility level model, PR } \\
(95 \% \mathrm{CI})\end{array}$ \\
\hline \multicolumn{6}{|l|}{ Maternal age at birth } \\
\hline$\leq 19$ (ref) & & 1.00 & & & 1.00 \\
\hline $20-34$ & & $0.09(0.01-0.63)^{*}$ & & & $0.14(0.11-0.17)^{* * *}$ \\
\hline$\geq 35$ & & $0.02(0.001-0.37)^{*}$ & & & $0.03(0.02-0.05)^{* * *}$ \\
\hline Maternal age at first birth & & $0.71(0.56-0.89)^{*}$ & & & $0.69(0.59-0.86)^{* * *}$ \\
\hline \multicolumn{6}{|l|}{ Mother's educational status } \\
\hline No education (ref) & & 1.00 & & & 1.00 \\
\hline Primary & & $0.78(0.55-1.12)$ & & & $0.88(0.68-1.14)$ \\
\hline Secondary & & $0.73(0.48-1.09)$ & & & $0.92(0.70-1.21)$ \\
\hline Higher & & $1.08(0.71-1.65)$ & & & $1.39(0.96-2.02)$ \\
\hline \multicolumn{6}{|l|}{ Mother's working status } \\
\hline No (ref) & & 1.00 & & & 1.00 \\
\hline Yes & & $0.64(0.44-0.94) *$ & & & $0.87(0.75-1.01)$ \\
\hline \multicolumn{6}{|l|}{ Husband's educational status } \\
\hline No education (ref) & & 1.00 & & & 1.00 \\
\hline Primary & & $1.19(0.92-1.55)$ & & & $1.17(0.96-1.43)$ \\
\hline Secondary & & $1.00(0.78-1.30)$ & & & $1.02(0.81-1.27)$ \\
\hline Higher & & $1.15(0.80-1.65)$ & & & $1.23(0.92-1.65)$ \\
\hline \multicolumn{6}{|l|}{ Sex of the household head } \\
\hline Male (ref) & & 1.00 & & & 1.00 \\
\hline Female & & $0.72(0.51-1.02)$ & & & $0.75(0.61-0.93)^{* * * *}$ \\
\hline \multicolumn{6}{|l|}{ Total children ever born } \\
\hline$\leq 2$ (ref) & & 1.00 & & & 1.00 \\
\hline$>2$ & & $1.21(0.96-1.52)$ & & & $1.05(0.91-1.22)$ \\
\hline
\end{tabular}




\begin{tabular}{|c|c|c|}
\hline Little exposed (ref) & 1.00 & 1.00 \\
\hline Moderate exposed & $1.13(0.86-1.47)$ & $1.22(0.98-1.51)$ \\
\hline Highly exposed & $0.75(0.57-1.00)^{*}$ & $0.92(0.77-1.09)$ \\
\hline \multicolumn{3}{|l|}{ Sibling's survival status } \\
\hline Yes (ref) & 1.00 & 1.00 \\
\hline No & $7.14(1.49-34.24)^{*}$ & $5.23(4.18-6.55)^{* * *}$ \\
\hline \multicolumn{3}{|l|}{ Wealth quintile } \\
\hline Poorest (ref) & 1.00 & 1.00 \\
\hline Poorer & $1.18(0.91-1.54)$ & $1.12(0.91-1.37)$ \\
\hline Middle & $0.93(0.70-1.22)$ & $0.93(0.73-1.19)$ \\
\hline Richer & $0.91(0.68-1.20)$ & $0.84(0.65-1.09)$ \\
\hline Richest & $0.62(0.38-1.01)$ & $0.61(0.45-0.85)^{* * *}$ \\
\hline \multicolumn{3}{|l|}{ Type of residential place } \\
\hline Urban (ref) & 1.00 & 1.00 \\
\hline Rural & $0.95(0.79-1.16)$ & $0.96(0.79-1.17)$ \\
\hline \multicolumn{3}{|l|}{ Division } \\
\hline Barishal (ref) & 1.00 & 1.00 \\
\hline Chattogram & $1.40(1.05-1.87)^{*}$ & $1.52(1.12-2.07)^{* * *}$ \\
\hline Dhaka & $1.23(0.90-1.68)$ & $1.25(0.90-1.74)$ \\
\hline Khulna & $0.95(0.68-1.32)$ & $0.99(0.69-1.41)$ \\
\hline Mymensingh & $1.34(0.98-1.81)$ & $1.34(0.97-1.85)$ \\
\hline Rajshahi & $0.92(0.66-1.28)$ & $0.97(0.69-1.38)$ \\
\hline Rangpur & $0.85(0.62-1.17)$ & $0.83(0.59-1.16)$ \\
\hline Sylhet & $2.72(2.03-3.64)^{* * *}$ & $2.83(2.08-3.86)^{* * *}$ \\
\hline \multicolumn{3}{|l|}{$\begin{array}{l}\text { General health service } \\
\text { readiness scores }\end{array}$} \\
\hline $\begin{array}{l}\text { Health facility management } \\
\text { system }\end{array}$ & & $0.92(0.88-1.19)$ \\
\hline Health facility infrastructure & & $0.86(0.74-1.12)$ \\
\hline
\end{tabular}


Long-acting contraceptives

Short-acting contraceptives

Facility's readiness scores

Long-acting contraceptives

Short term contraceptives

Average distance to the

\section{nearest health facility}

Note: ${ }^{*} \mathrm{p}<0.05,{ }^{* * *} \mathrm{p}<0.01$. Model summary for each model is presented in Table 4.
$0.78(0.64-0.95)$

$0.45(0.32-0.98)$

$0.95(0.48-1.13)$

$0.67(0.54-1.17)$

$1.45(1.23-1.75)$
$0.68(0.54-0.95) * * *$

$0.34(0.22-0.78) * * *$

$1.16(0.96-1.46)$

$1.45(0.98-1.48)$

$1.85(1.33-2.18) * * *$ 
medRxiv preprint doi: https://doi.org/10.1101/2021.07.05.21259952; this version posted July 7,2021 . The copyright holder for this preprint (which was not certified by peer review) is the author/funder, who has granted medRxiv a license to display the preprint in perpetuity.

\section{Discussion}

Analysing the nationally representative data in a multilevel framework, in this study, we explored the prevalence of SBI in Bangladesh and factors associated with SBI. Factors found to be positively and significantly associated with SBI are lower maternal age at first birth, the experience of the death of the second most recent child, average distance of nearby health facilities from the respondents' cluster, and residential location in the Chattogram and Sylhet divisions. The availability of modern contraceptives at the nearest health facilities and femaleheaded households were found to be protective of SBI.

The prevalence of SBI found in this study (26\%) is slightly higher than the global average (25\%) (33), but it is in the range of global range $(19.4 \%$ to $65.9 \%)(34,35)$. However, these global estimates used mostly 24 months interval to compute SBI, whereas, in this study, we considered 33 months following the WHO guideline. In that consideration, our observed prevalence may be lower than a global estimate of SBI based on the WHO guideline. This estimate for Bangladesh, which may be relevant for other LMICs, will help make evidencebased policies and programs for SBI reduction. Indeed, the target for SBI reduction was rooted around two decades ago, in 2000, as part of the Millennium Development Goals and remains a priority in the Sustainable Development Goals $(10-13,20)$. The focus of the current development goals is to improve maternal health and reduce adverse consequences during pregnancy and childbirth, which are major causes of maternal and child mortality in LMICs $(36,37)$.

We found a higher likelihood of SBI among women who gave their most recent birth at the age of 19 or earlier. Our finding of a relatively high prevalence of SBI among younger women is similar to that reported in some studies conducted in LMICs $(16,33,38,39)$. In most LMICs, 
medRxiv preprint doi: https://doi.org/10.1101/2021.07.05.21259952; this version posted July 7, 2021. The copyright holder for this preprint (which was not certified by peer review) is the author/funder, who has granted medRxiv a license to display the preprint in perpetuity. It is made available under a CC-BY-ND 4.0 International license.

many women marry before reaching 18 . Younger women are sexually more active than older women. Also, younger women are generally more fertile (40), and at this early age, they are unaware of reproductive health, contraception, and the importance of birth spacing. Besides, the social norm plays a key role both in early marriage and service-seeking behaviour after pregnancy. For instance, many women avoid facility-based reproductive healthcare services, as they feel uncomfortable in seeking services from male providers and there is a shortage of female providers (41). Moreover, the literature suggests that very young women are likely to be economically disadvantaged, which may further restrict their access to and use of modern contraception and possibly explains this association $(8,42)$.

This study found a lower likelihood of SBI among participants living in households headed by a woman. In our data, around $14 \%$ of households were headed by a woman. Although no study so far has explored the reasons for such association, there may have several explanations. First, women are usually more aware than men about pregnancy complication and their connection with SBI. They may have gained this awareness from their fertility experiences. If they are the heads, they may avoid SBI for themselves and/or recommend others in their households to avoid shorter intervals. Second, in some of these households, the study participants may have identified themselves as the heads because their husbands were living abroad. In such circumstances, they have a lower probability of getting pregnancies in short intervals. Third, if women identified themselves as the head of the households, then they may have been enjoying decision-making power about birth intervals and/or the use of contraception.

Consistent with studies conducted in some other LMICs $(15,43)$, this study found that the welloff women were more likely to give birth in short intervals than the least well-off. Usually, less frequent $(44,45)$ and less effective contraception use $(44,45)$, no knowledge of emergency 
medRxiv preprint doi: https://doi.org/10.1101/2021.07.05.21259952; this version posted July 7, 2021. The copyright holder for this preprint (which was not certified by peer review) is the author/funder, who has granted medRxiv a license to display the preprint in perpetuity. It is made available under a CC-BY-ND 4.0 International license.

contraception (44), or the combinations of these contraception-using behaviours are more common among the less affluent women. These behaviours lead to a consistently higher risk of unintended pregnancy (41) and most of them in short intervals. Also, women's knowledge and affordability of modern contraception use are linked to their economic status. Moreover, less affluent women usually have lower autonomy over their reproductive life and access to health facilities. Women of poor households are subject to religious and social norms that may restrict their movements in a male-dominated society. Indeed, several social determinants of health are interlinked and they both separately and together may affect women's access to and use of modern contraception.

We found women's experience of the death of a child born from their second recent pregnancy was a strong predictor of SBI. This association is consistent with previous findings of some studies conducted in LMICs $(15,46-48)$ and there are at least two possible explanations for this. First, the death of an infant suddenly terminates breastfeeding (49-51). This, in turn, triggers the resumption of ovulation and thereby increases the exposure duration of a new conception. Second, a previous adverse outcome may have a "replacement effect" $(52,53)$, which prompts women to soon get pregnant in an attempt to attain the desired number of surviving offspring at the end of their reproductive life. Third, depression from the experience of a child's death may also make women unaware of or indifferent to contraception use.

The provision of modern contraceptives at the nearest health facility from women's houses is a strong negative predictor of SBI. Also, the prevalence of SBI decreases with an increasing average distance of the nearest health facilities from women's residences. These relationships are reasonable, as the provision increases the availability and the smaller distance increases the accessibility. Service convenience, particularly in the post-partum period when movement is 
medRxiv preprint doi: https://doi.org/10.1101/2021.07.05.21259952; this version posted July 7, 2021. The copyright holder for this preprint (which was not certified by peer review) is the author/funder, who has granted medRxiv a license to display the preprint in perpetuity. It is made available under a CC-BY-ND 4.0 International license.

considered risky, is crucial. Women in Bangladesh usually face restrictions in travelling long distances and these restrictions are linked with gender, community norms, transport and time barriers.

To our knowledge, this is the first study in the context of LMICs that examines the determinants of SBI using the linked population survey and health facility data. The linking of two national datasets enabled us to adjust the influence of health facility-level factors, including the availability of modern contraceptives and the average distance of women's houses in the respective clusters from health facilities. These facility-level factors substantially determine the prevalence of SBI and often mediate the influence of individual-, household-, and community-level factors of SBI. Moreover, we used a robust statistical model-building technique and adjusted for individual-, household-, community-, and health facility-level confounders, which increased the precision of our findings. Thus, we believe, our findings will inform evidence-based policies and programs in Bangladesh and other LMICs in reducing the prevalence of SBI. However, a limitation of this study is its cross-sectional data; therefore, the associations are correlational rather than causal. To ensure the privacy of the respondents, the DHS displaced BDHS cluster locations up to five $\mathrm{km}$ in rural areas and two $\mathrm{km}$ in urban areas. This displacement may have changed the average distance of the nearest health facilities from women's houses and other estimates presented in this study. However, the DHS ensured that the clusters are located in their original administrative division. Although this displacement may have changed the average distance of the nearest health facilities from women's houses and other estimates presented in this study, this variation is likely to be random. Also, some women may have sourced contraceptives from health facilities located further away than closest ones and/or from private facilities. 
medRxiv preprint doi: https://doi.org/10.1101/2021.07.05.21259952; this version posted July 7,2021 . The copyright holder for this preprint (which was not certified by peer review) is the author/funder, who has granted medRxiv a license to display the preprint in perpetuity. It is made available under a CC-BY-ND 4.0 International license.

\section{Conclusion}

This study found more than one-fourth of live births in Bangladesh occurred in short intervals. The prevalence of SBI was lower among women of relatively high ages, residing in the households headed by a female, and of the richest wealth quintile. The availability of modern contraceptives at the nearest health facility from women's respective clusters is protective of SBI. Also, women's experience of the death of their second most recent child is a strong predictor of SBI. Increased availability of modern contraceptives in all health facilities and targeted programs for women of younger ages or women who had adverse pregnancy experiences should be prioritized in the policies and programmes to reduce SBI and associated adverse outcomes. Further studies examining the geographical hotspots of SBI and associated factors may also help in targeted interventions.

Declaration of interests: The authors declare that they have no known competing financial interests or personal relationships that could have appeared to influence the work reported in this paper.

Acknowledgement: The authors thank the MEASURE DHS for granting access to the 2011 and 2017/18 BDHS data.

Funding: This research did not receive any specific grant from funding agencies in the public, commercial, or not-for-profit sectors.

Authors' contributions: MNK and MZI designed the study, performed the data analysis, and wrote the first draft of this manuscript. MMI and MMR critically reviewed and edited the previous versions of this manuscript. All authors approved this final version of the manuscript.

Data availability: The datasets used and analysed in this study are available from the Measure DHS website: https://dhsprogram.com/data/available-datasets.cfm 
medRxiv preprint doi: https://doi.org/10.1101/2021.07.05.21259952; this version posted July 7,2021 . The copyright holder for this preprint (which was not certified by peer review) is the author/funder, who has granted medRxiv a license to display the preprint in perpetuity.

\section{References:}

1. WHO. Report of a WHO technical consultation on birth spacing: Geneva, Switzerland 13-15 June 2005. 2007 [cited 2021 Jan 18]; Available from: https://apps.who.int/iris/handle/10665/69855

2. Adam I, Ismail MH, Nasr AM, Prins MH, Smits LJM. Low birth weight, preterm birth and short interpregnancy interval in Sudan. J Matern Fetal Neonatal Med. 2009 Nov 1;22(11):1068-71.

3. Grisaru-Granovsky GS, Haklai E SZ, Schimme A MM. Effect of interpregnancy interval on adverse perinatal outcomes — a national study. 2009;Contraception 80(6): 512-518.

4. Hussaini KS, Ritenour D, Coonrod DV. Interpregnancy Intervals and the Risk for Infant Mortality: A Case Control Study of Arizona Infants 2003-2007. Matern Child Health J. 2013 May 1;17(4):646-53.

5. Conde-Agudelo, Rosas-Bermúdez A K-GA, Ana C. Effects of birth spacing on maternal health: a systematic review. American journal of obstetrics and gynecology. 2007;196(4):297-308.

6. Davanzo, Razzaque J RA, Hale M AL, Khan K MMA, Gausia G, Kaniz. The effects of birth spacing on infant and child mortality, pregnancy outcomes, and maternal morbidity and mortality in Matlab, Bangladesh. Technical Consultation and Review of the Scientific Evidence for Birth Spacing. 2004;

7. Rutstein, Shea O. Trends in birth spacing. Calverton, Maryland, USA: ICF Macro: USAID; 2011. Report No.: 28.

8. Khan MN, Harris ML, Loxton D. Assessing the effect of pregnancy intention at conception on the continuum of care in maternal healthcare services use in Bangladesh: Evidence from a nationally representative cross-sectional survey. PLOS ONE. 2020 Nov 20;15(11):e0242729.

9. Rahman A, Rahman M, Pervin J, Razzaque A, Aktar S, Ahmed JU, et al. Time trends and sociodemographic determinants of preterm births in pregnancy cohorts in Matlab, Bangladesh, 1990-2014. BMJ Glob Health. 2019 Aug 1;4(4):e001462.

10. Nisha MK, Alam A, Islam MT, Huda T, Raynes-Greenow C. Risk of adverse pregnancy outcomes associated with short and long birth intervals in Bangladesh: evidence from six Bangladesh Demographic and Health Surveys, 1996-2014. BMJ Open [Internet]. 2019 Feb 22 [cited 2021 Jan 18];9(2). Available from: https://www.ncbi.nlm.nih.gov/pmc/articles/PMC6398728/

11. Ahammed B, Kabir MR, Abedin MM, Ali M, Islam MA. Determinants of different birth intervals of ever married women: Evidence from Bangladesh. Clin Epidemiol Glob Health. 2019 Sep 1;7(3):450-6.

12. de Jonge HC, Azad K, Seward N, Kuddus A, Shaha S, Beard J, et al. Determinants and consequences of short birth interval in rural Bangladesh: a cross-sectional study. BMC Pregnancy Childbirth. 2014 Dec 24;14(1):427. 
medRxiv preprint doi: https://doi.org/10.1101/2021.07.05.21259952; this version posted July 7,2021 . The copyright holder for this preprint (which was not certified by peer review) is the author/funder, who has granted medRxiv a license to display the preprint in perpetuity. It is made available under a CC-BY-ND 4.0 International license .

13. Khan J, Bari W, Latif M. Trend of determinants of birth interval dynamics in Bangladesh. BMC Public Health. 2016 Sep 5;16.

14. Tessema GA, Zeleke BM, Ayele TA. Birth Interval and its Predictors among Married Women in Dabat District, Northwest Ethiopia: A Retrospective Follow Up Study on JSTOR [Internet]. 2016 [cited 2021 Jun 1]. Available from: https://www.jstor.org/stable/23485919?seq=1

15. Ajayi AI, Somefun OD. Patterns and determinants of short and long birth intervals among women in selected sub-Saharan African countries. Medicine (Baltimore). 2020 May;99(19):e20118.

16. Nausheen S, Bhura M, Hackett K, Hussain I, Shaikh Z, Rizvi A, et al. Determinants of Short Birth Intervals among married women in Karachi, Pakistan. medRxiv. 2020 Aug $14 ; 2020.08 .13 .20174110$.

17. Tengku Ismail TA, Hamzah TNBT, Hassan MHM, Mahmood NMZN. Prevalence and factors associated with short birth spacing among Malay women in Kota Bharu, Kelantan, Malaysia. Int Med J. 2008 May 1;15:131-6.

18. Singh R, Tripathi V, Kalaivani M, Singh K, Dwivedi SN. Determinants of Birth Intervals in Tamil Nadu in India: Developing Cox Hazard Models with Validations and Predictions. Rev Colomb Estad. 2012 Jun;35(SPE2):289-307.

19. Gebrehiwot S, Abera G, Tesfay K, Tilahun W. Short birth interval and associated factors among women of child bearing age in northern Ethiopia, 2016. BMC Womens Health. 2019 Jul 2;19.

20. Islam H. An Analysis Of Birth Intervals In Bangladesh Using Frailty Models. J Asiat Soc Bangladesh Sci. 2016 Dec 25;42(2):243-9.

21. Rose M, Abderrahim N, Stanton C, Helsel D. Maternity care: a comparative report on the availability and use of maternity services. Data from the Demographic and Health Surveys Women's Module and Services Availability Module 1993-1996. undefined [Internet]. 2001 [cited 2021 Jun 5]; Available from: /paper/Maternity-care\%3A-acomparative-report-on-the-and-use-RoseAbderrahim/f3dc6d5567d91d543c37910ed4b4c133a3418ea4

22. Kroeger A. Anthropological and socio-medical health care research in developing countries. Soc Sci Med. 1983;17(3):147-61.

23. Skiles MP, Burgert CR, Curtis SL, Spencer J. Geographically linking population and facility surveys: methodological considerations. Popul Health Metr. 2013 Aug $8 ; 11(1): 14$.

24. USAID. Perez-Heydrich, Carolina, Joshua L. Warren, Clara R. Burgert, and Michael E. Emch. 2013. Guidelines on the Use of DHS GPS Data. Spatial Analysis Reports No. 8. Calverton, Maryland, USA: ICF International. 2013;

25. BDHS. National Institute of Population Research and Training (NIPORT), and ICF. 2020. Bangladesh Demographic and Health Survey 2017-18. Dhaka, Bangladesh, and Rockville, Maryland, USA: NIPORT and ICF. 2017; 
medRxiv preprint doi: https://doi.org/10.1101/2021.07.05.21259952; this version posted July 7,2021 . The copyright holder for this preprint (which was not certified by peer review) is the author/funder, who has granted medRxiv a license to display the preprint in perpetuity. It is made available under a CC-BY-ND 4.0 International license.

26. BHFS. National Institute of Population Research and Training (NIPORT) and ICF. 2019. Bangladesh Health Facility Survey 2017. Dhaka, Bangladesh: NIPORT, ACPR, and ICF. 2017;

27. Kroeger A. Anthropological and socio-medical health care research in developing countries - PubMed. Soc Sci Med. 1983;17:147-61.

28. Tegegne TK, Chojenta C, Forder PM, Getachew T, Smith R, Loxton D. Spatial variations and associated factors of modern contraceptive use in Ethiopia: a spatial and multilevel analysis. BMJ Open. 2020 Oct 1;10(10):e037532.

29. Khan M, Islam M. Spatial variation and associated factors of modern contraceptives use in Bangladesh: Evidence from the linked survey and healthcare facility data. medRxiv. 2021;

30. Austin PC, Stryhn H, Leckie G, Merlo J. Measures of clustering and heterogeneity in multilevel Poisson regression analyses of rates/count data. Stat Med. 2018;37(4):57289.

31. J D Barros A, Hirakata V. Alternatives for logistic regression in cross-sectional studies: an empirical comparison of models that directly estimate the prevalence ratio. BMC Med Res Methodol. 2003 Oct 20;3.

32. O’Connell AA, McCoach DB. Multilevel modeling of educational data [Internet]. Charlotte, NC: IAP; 2008 [cited 2021 Jun 29]. Available from: http://public.ebookcentral.proquest.com/choice/publicfullrecord.aspx?p=3315388

33. Aleni M, Mbalinda SN, Muhindo R. Birth Intervals and Associated Factors among Women Attending Young Child Clinic in Yumbe Hospital, Uganda. Int J Reprod Med. 2020 Jan 4;2020:e1326596.

34. Mahande MJ, Obure J. Effect of interpregnancy interval on adverse pregnancy outcomes in northern Tanzania: a registry-based retrospective cohort study. BMC Pregnancy Childbirth. 2016 Jun 7;16(1):140.

35. Bassey G, Nyengidiki TK, Dambo ND. Determinants of interpregnancy interval among parturient in Port Harcourt, Nigeria [Internet]. 2016 [cited 2021 Jun 1]. Available from: https://www.smjonline.org/article.asp?issn=1118-

8561; year $=2016$; volume $=19 ;$ issue $=4$; :page $=180$; epage $=184$; aulast $=$ Bassey

36. Max. MDG 5: Improve maternal health [Internet]. Millennium Development Goals. 2016 [cited 2021 Jun 1]. Available from: https://www.mdgmonitor.org/mdg-5-improvematernal-health/

37. Callister LC, Edwards JE. Sustainable Development Goals and the Ongoing Process of Reducing Maternal Mortality. J Obstet Gynecol Neonatal Nurs. 2017 May;46(3):e5664.

38. Aychiluhm SB, Tadesse AW, Mare KU, Abdu M, Ketema A. A multilevel analysis of short birth interval and its determinants among reproductive age women in developing regions of Ethiopia. PLOS ONE. 2020 Aug 26;15(8):e0237602. 
medRxiv preprint doi: https://doi.org/10.1101/2021.07.05.21259952; this version posted July 7,2021 . The copyright holder for this preprint (which was not certified by peer review) is the author/funder, who has granted medRxiv a license to display the preprint in perpetuity. It is made available under a CC-BY-ND 4.0 International license.

39. Kurniawati D, Prasetyo S. Birth Intervals among Multiparous Women in Indonesia. Kesmas Natl Public Health J. 2016 Jun 21;10(4):150.

40. Pimentel J, Ansari U, Omer K, Gidado Y, Baba MC, Andersson N, et al. Factors associated with short birth interval in low- and middle-income countries: a systematic review. BMC Pregnancy Childbirth. 2020 Mar 12;20(1):156.

41. Khan MN, Harris M, Loxton D. Modern Contraceptive Use Following an Unplanned Birth in Bangladesh: An Analysis of National Survey Data. Int Perspect Sex Reprod Health. 2020 May 12;46:77-87.

42. Khan MN, Harris ML, Loxton D. Does unintended pregnancy have an impact on skilled delivery care use in Bangladesh? A nationally representative cross-sectional study using Demography and Health Survey data. J Biosoc Sci. undefined/ed;1-17.

43. Hailu D, Gulte T. Determinants of Short Interbirth Interval among Reproductive Age Mothers in Arba Minch District, Ethiopia. Int J Reprod Med [Internet]. 2016 [cited 2021 Jan 18];2016. Available from: https://www.ncbi.nlm.nih.gov/pmc/articles/PMC4863097/

44. Trussell J, Koenig J, Ellertson C, Stewart F. Preventing unintended pregnancy: the costeffectiveness of three methods of emergency contraception. Am J Public Health. 1997 Jun;87(6):932-7.

45. Finer LB, Zolna MR. Declines in Unintended Pregnancy in the United States, 20082011. N Engl J Med. 2016 Mar 3;374(9):843-52.

46. Chen LC, Ahmed S, Gesche M, Henry Mosley W. Prospective study of birth interval dynamics in rural Bangladesh. Popul Stud. 1974 Jul;28(2):277-97.

47. Whitworth A, Stephenson R. Birth spacing, sibling rivalry and child mortality in India. Soc Sci Med 1982. 2002 Dec;55(12):2107-19.

48. Yohannes S, Wondafrash M, Abera M, Girma E. Duration and determinants of birth interval among women of child bearing age in Southern Ethiopia. BMC Pregnancy Childbirth. 2011 May 20;11(1):38.

49. Park CB, Islam MA, Chakraborty N, Kantner A. Partitioning the Effect of Infant and Child Death on Subsequent Fertility: An Exploration in Bangladesh. Popul Stud. 1998;52(3):345-56.

50. Singh NS, Singh NS, Narendra RK. Postpartum Amenorrhoea among Manipuri Women: A Survival Analysis. J Health Popul Nutr. 2012 Mar;30(1):93-8.

51. Hossain MB, Phillips JF, Legrand TK. The impact of childhood mortality on Fertility in six rural Thanas of Bangladesh. Demography. 2007 Nov 1;44(4):771-84.

52. Population NRC (US) C on, Montgomery MR, Cohen B. Effect of a Child's Death on Birth Spacing: A Cross-National Analysis [Internet]. From Death to Birth : Mortality Decline and Reproductive Change. National Academies Press (US); 1998 [cited 2021 Jun 29]. Available from: https://www.ncbi.nlm.nih.gov/books/NBK233806/ 
medRxiv preprint doi: https://doi.org/10.1101/2021.07.05.21259952; this version posted July 7, 2021. The copyright holder for this preprint (which was not certified by peer review) is the author/funder, who has granted medRxiv a license to display the preprint in perpetuity. It is made available under a CC-BY-ND 4.0 International license.

53. Soest A van, Saha UR. Relationships between infant mortality, birth spacing and fertility in Matlab, Bangladesh. PLOS ONE. 2018 Apr 27;13(4):e0195940. 